\title{
O que é que uma diva tem? Cantoras brasileiras, vozes, corpos e poderes vistos por entendidos
}

\author{
Rafael da Silva Noleto
}

resumo Dentro de certas redes de sociabilidade homossexual, o adjetivo "poderosa" é frequentemente acionado como um marcador destinado à classificação, hierarquização, comparação, qualificação e representação de ídolos femininos admirados por homens homossexuais. Partindo de etnografia realizada em Belém (Pará), este texto objetiva compreender quais as noçôes de poder articuladas por homens homossexuais - com identidade e performance de gênero reconhecidas, por eles, como masculinas - para designar suas cantoras favoritas. Evidenciando que, na maioria dos discursos, esse "poder" das cantoras transcende predicados estritamente musicais e se revela inscrito na totalidade performática de seus corpos, este artigo visa discutir acerca dos "poderes", "perigos", "centralidades" e "periferias" do corpo.

palavras-chave Homossexualidade. Performance. Cantoras Brasileiras. MPB. Corpo.

\section{“Nós somos apenas vozes" - Percursos metodológicos}

\section{- Vai, Bethâniaaa! Maravilhosaaaa!!}

Essas palavras, gritadas enfaticamente e embevecidas de encantamento, são as palavras de um fă anônimo, mas que, para mim, fora eternizado pelo registro, ao vivo, de um show da cantora Maria Bethânia, lançado em LP no ano de 1969 e intitulado simplesmente como "Maria Bethânia ao vivo". As palavras deste fã me perseguiram e é provável que ele mesmo tenha sido um (per)seguidor de Maria Bethânia ao longo de todos estes anos, talvez seja hoje um fã sexagenário que continua a gritar (agora mais rouco) ou, quem sabe, tenha apenas se eternizado ocasionalmente por ter comparecido àquela única apresentação de Maria Bethânia no dia em que seu show fora gravado em 1969.

Abandonando estas especulações, o fato é que, em todos os álbuns gravados ao vivo e lançados por Bethânia até hoje, há sempre uma voz masculina que grita adjetivos como "poderosa", "divina”, "maravilhosa" ou outros que lhes seja equivalente. Essas vozes masculinas ficaram guardadas em mim. Essas vozes anônimas não se dirigem apenas à Maria Bethânia, mas a outras vozes femininas que cantam e que encontram nos homossexuais um público consumidor fiel, que se reconhece nelas.

Não pretendo dizer que o fã anônimo que gritou "Maravilhosaaaa!!", em 1969, seja um homossexual. Não tenho meios para realizar tal afirmação, mas posso dizer que este tipo de adjetivo é frequentemente verbalizado por homossexuais como um qualificador ou marcador de status que localiza suas cantoras prediletas dentro de uma cultura musical gay. As vozes abstratas que estão gravadas nestes discos, tornam-se, agora, concretas para mim à medida que me aproximo delas - através de meus interlocutores reais - para estabelecer um diálogo com e sobre elas. São vozes que falam a respeito de vozes. Nesta pretensão de dar voz aos "meus" "nativos", intuo que talvez eu tenha 
encontrado uma forma de exorcizar estas vozes de meus ouvidos ou, provavelmente, eu apenas esteja procurando outra maneira de gritar junto com elas.

O poder de encantamento, atribuído pelos fâs à música dessas cantoras, torna inevitável uma associaçấo metafórica com o universo da magia. Malinowski (1976), ao analisar e explicar as funçóes e o uso da magia por parte do Trobriand, afirmou que

Em todos esses atos mágicos o objeto é colocado bem ao alcance da voz, em uma posição adequada. Freqüentemente o objeto é colocado dentro de um recipiente ou envoltório, de modo que a voz penetre em um espaço fechado e se concentre sobre a substância que vai ser encantada (Ib., Idem, p. 300)

O intuito de Malinowski ao discorrer sobre a magia trobriand era ressaltar - além da importância vital que o encantamento (ou feitiçaria) tinha para toda a organização social daquele grupo - que, para os nativos das ilhas Trobriand, "a força da magia não reside nas coisas; ela está dentro do homem e só pode escapar através da voz" (Ib., Idem, p. 303). A exposição do autor deixa claro que, na compreensão difundida entre "seus" nativos, "é a voz do recitador que transmite a virtude" (Ib., p. 302), materializada em qualidades transferidas aos objetos, atividades econômicas e pessoas por meio dos poderes mágicos do feiticeiro. Para os trobriand, "a mente, nanola - termo que compreende a inteligência, o poder de discriminação, a capacidade para aprender fórmulas mágicas, e todas as formas de habilidades não manuais, bem como as qualidades morais - situa-se em algum ponto da laringe" (Ib., Idem, p. 303).
Obviamente, Malinowski escrevia em contexto histórico diferente deste em que minha pesquisa se desenvolve, possuía outros objetivos para realizar sua empreitada, analisava uma sociedade que não compartilhava do modelo de organização social em que estamos enredados e, principalmente, realizava suas análises a partir de perspectivas teóricas funcionalistas, as quais, ele mesmo, ajudou a inaugurar na Antropologia. Com todas as diferenças que se possam tornar evidentes entre a sua pesquisa e esta que faço, considero válida a utilização da metáfora da "magia" para falar deste universo musical de "encantamento".

Em minha etnografia, as "feiticeiras" são mulheres cantoras, os "feitiços" são cançôes, a "virtude" é a voz, os "recipientes fechados" são casas de espetáculo e os "enfeitiçados" não são objetos, mas homens homossexuais. Utilizo essa imagem de magia, encantamento ou feitiçaria para iniciar as reflexóes acerca dos atributos de poder e carisma, relacionados a essas "cantoras-feiticeiras", que pretendo discutir ao longo destas páginas.

Antes de evidenciar o perfil e os critérios de escolha dos "enfeitiçados" que se tornaram interlocutores deste trabalho, desejo refutar qualquer tipo de essencialização ou vinculação equivocada que possa existir entre o gosto musical deles e as suas homossexualidades. Este texto náo parte de um pressuposto essencializador que atribui o gosto por cantoras - e mais precisamente por essas cantoras que serão, aos poucos, apresentadas - a uma condição prévia para marcar a homossexualidade de meus interlocutores. Entendo que os estudos queer propõem, justamente, uma desnaturalização da compreensão dos sujeitos e dos gêneros. Assim, recuso uma naturalização do gosto por essas cantoras como sendo uma ontologia homossexual por compreender a crítica queer quando afirma que "os resquícios de essencialismo na 
O QUE É QUE UMA DIVA TEM? CANTORAS BRASILEIRAS, VOZES, CORPOS E PODERES VISTOS POR ENTENDIDOS 47

teoria social permanecem em um conceito (ou pressuposto) que perpassa a maioria de suas correntes até os nossos dias: a normalidade" (Miskolci, 2009, p. 162). Portanto, não quero produzir um "homossexual normal", marcado pelo fato de gostar de cantoras, ao mesmo tempo em que produziria um "homossexual anormal" por não compartilhar deste tipo de preferência musical. Vale lembrar que essas cantoras possuem públicos heterogêneos, compostos por faixas etárias, classes sociais, orientaçóes sexuais, nacionalidades e raças distintas entre si. Não pretendo esconder a multiplicidade de fatores identitários que circundam o público dessas artistas, embora esteja trabalhando com o preceito de que os próprios fấs dessas cantoras as classificam como "cantoras gay". Considerando que "a concepção fortemente polarizada dos gêneros esconde a pluralidade existente em cada um dos pólos" (Louro, 1997, p. 52), é importante destacar que, assim como existem diversas feminilidades e masculinidades, configuram-se também várias homossexualidades. Creio que exista, dentro dessas homossexualidades, uma multiplicidade de gostos, preferências e identidades que não necessariamente sejam perpassadas por uma relação entre o sujeito gay e a arte. Entretanto, acredito que, para os sujeitos homossexuais que, especificamente, se reconhecem como fấs dessas cantoras apresentadas a seguir, há certas convergências de pensamento que demonstram a existência de um imaginário construído em torno delas.

Para serem convidados a colaborar com este trabalho, os interlocutores precisaram preencher os seguintes requisitos: ser homem, homossexual, reconhecer-se com uma identidade de gênero masculina, fã de uma cantora e não desenvolver atividades profissionais relacionadas à música.

A escolha do homossexual masculino como principal sujeito desta pesquisa se deu pelo fato de que percebo o grande espaço que muitas mulheres de destaque social (canto- ras, atrizes, modelos, apresentadoras de TV e personalidades da mídia) ocupam nas redes de sociabilidade homossexual das quais faço parte ou com as quais mantenho contato. Essas mulheres se constituem como assunto constante entre homossexuais, sendo objeto de análise desses sujeitos, ativando o uso de uma semântica que cria "teias de significados" (Geertz, 1989), concedendo um status sóciocultural de inteligência e refinamento àqueles homossexuais que dominam os códigos de uma cultura musical (e junto a ela uma cultura literária, estética, "fashionista") que demanda saberes específicos, valorizados nessas relaçóes de sociabilidade. Não tenho meios precisos para afirmar que esses aspectos sejam ou não valorizados entre pessoas heterossexuais de maneira hegemônica, mas posso sugerir que, no contexto da homossexualidade masculina, o domínio desses códigos e a demonstração de um conhecimento vinculado à arte e à moda são amplamente valorizados, constituindo-se em marcadores de status e, portanto, percebidos como um "capital cultural" (Bourdieu, 2007) dos sujeitos que integram essas redes.

Parece necessário esclarecer a concepção de sujeito "homossexual" com a qual venho trabalhando. No intuito de enfatizar o caráter polissêmico que esta categoria denota, recorro ao trabalho de Fry e MacRae (1985) para concordar com a afirmativa de que "não há nenhuma verdade absoluta sobre o que é a homossexualidade e que as ideias e práticas a ela associadas são produzidas historicamente no interior de sociedades concretas e que são intimamente relacionadas com o todo dessas sociedades" (Ib., Idem, p. 10) [grifo dos autores]. Carrara e Simóes (2007), apontam para o momento em que

Mary McIntosh reuniu evidências sociológicas e históricas disponíveis em 1968 para sugerir 
que, embora desejos e comportamentos homossexuais pudessem existir em diferentes épocas e sociedades, somente em algumas se produzia uma identidade homossexual específica, conforme preocupaçóes com as definições e os limites do que é aceitável em termos de conduta sexual (Ib., Idem, p. 82).

Butler (2010) compreende a orientação homossexual como uma das maneiras alternativas de vivência da sexualidade, afastando-se de amarras heteronormativas que alinhavam os gêneros em sistemas de inteligibilidade, os quais pressupóem certa continuidade - direcionada à orientação heterossexual - entre sexo, gênero, performance de gênero e desejo sexual. A autora acredita que a experiência da homossexualidade - ou de outras sexualidades não pautadas na heteronormatividade - articula a produção de "'sujeitos' que não apenas ultrapassam os limites da inteligibilidade cultural como efetivamente expandem as fronteiras do que é de fato culturalmente inteligível" (Ib., Idem, p. 54).

Diante da polissemia identificável no conceito de homossexualidade, procurei trabalhar com o pressuposto de que meus interlocutores se reconhecem como homossexuais. Tal reconhecimento está fortemente pautado no fato de que eles se identificam como homens que, predominantemente, mantêm relaçóes afetivo-sexuais com outros homens.

Há um aspecto que deve ser mencionado e que se refere ao fato de que escolhi homens homossexuais que se reconhecem em identidades de gênero masculinas. Essa opção foi uma tentativa de compreender melhor o universo social de homens gays cuja performance e identidade de gênero são assumidas como masculinas, mas que apresentam como principal referência cultural, comportamental ou mesmo intelectual, mulheres cantoras de grande destaque na música brasileira. A intenção foi fugir de associaçóes óbvias como, por exemplo, poderia ocorrer se minha pesquisa abrangesse homens com identidades e performances de gênero consideradas femininas, cujos ídolos seriam facilmente apontados como "modelos ideais" para que estes sujeitos "aprendam" formas de ser mulher.

Entretanto, minha pesquisa dialoga, majoritariamente, com homens homossexuais que pouco se identificam com o gênero feminino em suas performances corporais, são sujeitos que não necessariamente desejam "ser" mulher ou performatizar "como se fosse" uma mulher. Tais interlocutores buscam nessas cantoras uma referência de vida que é acionada para articular sociabilidades e explicar seus próprios trânsitos dentre os grupos homossociais ${ }^{3}$ dos quais fazem parte. Mesmo nesta configuração anteriormente discutida, esses homens realizam jogos de "negociaçôes" entre "feminilidades" e "masculinidades" nos quais inscrevem em seus corpos - e em suas performatividades como um todo - traços performativos de suas cantoras favoritas, promovendo assim uma imbricação de gestos, palavras, modos de ser, estar e vestir oriundos da mistura dos universos do fấ e da cantora.

Durante a elaboração deste trabalho em seu âmbito teórico e empírico, um questionamento em especial apareceu: como manter uma presença duradoura dentro do campo quando se realiza uma etnografia urbana, perpassada por vários fatores que impedem o estabelecimento de uma relação de convivência contínua com os "nativos"? O legado de Malinowski (1976) e sua fundamental contribuição para o estabelecimento de um método de pesquisa em Antropologia, aliada à leitura que, naquele período de questionamentos, eu fazia da obra de Maybury-Lewis (1990), me levaram a tentar encontrar maneiras de estar, senão fisi- 
O QUE É QUE UMA DIVA TEM? CANTORAS BRASILEIRAS, VOZES, CORPOS E PODERES VISTOS POR ENTENDIDOS 49

camente, mas virtualmente próximo de meus interlocutores. Talvez eu tivesse a esperança fantasiosa de colecionar histórias e exemplos que, futuramente, me serviriam como ferramentas utilizáveis para produzir um texto tão rico de acontecimentos e emoçóes como a narrativa de Maybury-Lewis. Mas, ao pensar nisso e (naquele momento) ter esses dois autores como paradigmas do "estar lá" (Geertz, 2009), fui conduzido a encontrar formas de manter uma presença mais constante na vida de meus interlocutores. Claramente inspirado na problematização feita por Martin (2006) e nas soluções por ela encontradas para ultrapassar certos limites encontrados na realização de uma etnografia em contextos urbanos, recorri à internet e ao telefone como uma extensão de possibilidades do "estar lá". E foi, a partir disso, que pude coletar outros depoimentos, ainda mais espontâneos, fora do formalismo (mesmo implícito) de uma entrevista gravada, fortalecer os laços de confiança com os interlocutores e, principalmente, aprofundar minhas análises.

Seis (06) vozes masculinas foram selecionadas para dialogar comigo. Seus nomes verdadeiros foram omitidos para preservar suas identidades. Os novos nomes escolhidos estão diretamente relacionados ao universo musical da cantora eleita, por cada um deles, como ídolo. Foram selecionadas denominaçóes que fazem referência a gravaçóes, álbuns e aspectos relativos à trajetória artística dessas intérpretes. Os nomes que usarei para fazer referência a todos eles em sua individualidade são: Tamba-tajá e Atrevido (32 e 35 anos, fấs de Fafá de Belém), Pirata e Brasileirinho (35 e 32 anos, fẫs de Maria Bethânia), Fatal (45 nos, fá de Gal Costa) e Pimentinha (nâo revela a idade, fã de Elis Regina).

No contexto desta pesquisa, entende-se como cantora uma mulher que exerce profissionalmente a atividade do canto (seja popular ou erudito); vinculada ou não a uma grava- dora, mas que lance com regularidade álbuns de circulação nacional; que tenha nascido no Brasil ou que, sendo estrangeira, seja reconhecida como uma cantora "brasileira" (Carmen Miranda é um exemplo) e, por fim, que seja reconhecida por seus fấs homossexuais como um ícone relacionado ao imaginário gay.

Sendo músico e homossexual, tive que lidar, no decorrer deste processo, com as vantagens e desvantagens de pesquisar dentro de um universo que, para mim, é tão familiar. As desvantagens se resumiam ao temor de não conseguir o distanciamento (e o "estranhamento") necessário para elaborar uma teoria a partir daquilo que é empiricamente familiar, fazendo com que esses fatos etnográficos fossem perpassados por uma ciência antropológica que lhes conferisse inteligibilidade e legitimidade no mundo acadêmico. "O estranhamento passa a ser não só a via pela qual se dá o confronto entre diferentes 'teorias', mas também o meio de auto-reflexão” (Peirano, 1990, p. 4) a partir do qual, gradativamente, fui construindo hipóteses e fortalecendo uma forma "externa" de olhar para o familiar.

Em contrapartida, houve vantagens quanto à familiarização com meu "lócus" etnográfico da homossexualidade e da canção popular. Eu sabia falar "a língua do santo" (Silva, 2006). Refletindo sobre etnografias desenvolvidas em terreiros de religióes de matriz africana, Vagner Gonçalves da Silva (Ib.) ressalta a importância de "dominar" certos códigos culturais e lingüísticos da realidade pesquisada para que se possa empreender um diálogo bem sucedido com os interlocutores durante o exercício etnográfico. Para o autor, "dominar" esses códigos de conduta e de linguagem significa, metaforicamente, saber "falar a língua do santo", possibilitando uma melhor inserção no campo e um entendimento mais profundo do sentido dos discursos coletados nas entrevistas. Falar a 
"língua do santo" é compreender certas categorias e expressões utilizadas pelos interlocutores, pois "não saber o significado dessas palavras é estar alijado da compreensão mínima dos termos de reconhecimento do grupo" (Ib., Idem, p. 48). Conhecendo "de perto" certos códigos $\mathrm{da}$ linguagem homossexual e estando a par da realidade musical vivenciada por meus interlocutores, percebi como vantagem o fato de que eu podia falar o mesmo "idioma" que eles.

Ao contatar os interlocutores para realizar as entrevistas e, portanto, "perseguir pessoas sutis com perguntas obtusas" (Geertz, 1989, p. 20), eu sugeria que os locais onde ocorreriam os diálogos fossem escolhidos pelo entrevistado. $\mathrm{Na}$ dúvida ou indiferença deste, eu escolhia o local com base naquilo que seria mais prático para o meu deslocamento e mais "rentável" para as entrevistas, ou seja, lugares de fácil acesso e sem muitas interferências externas como barulho ou intenso fluxo de pessoas. Quando entrei em contato com Pirata e pedi a ele que escolhesse o local de sua entrevista, ouvi a seguinte pergunta: "Onde Bethânia iria?" À qual ele mesmo respondeu: "Ah! Tem que ser um lugar que tenha natureza... Pode ser no Parque da Residência?"4

Percebi que, para todos os interlocutores, falar de seu universo musical e de sua cantora favorita constituía um grande prazer comparável ao que, para um torcedor, constitui imensa satisfação a oportunidade de falar de esporte e de seu time predileto. Mas estas falas não eram vazias, antes, eram reflexivas. Constituíam-se em falas que, a partir das perguntas realizadas, eram orientadas a refletir sobre as sociabilidades homoafetivas envolvidas em suas experiências musicais e a pensar nas próprias palavras cotidianamente usadas para dizer algo sobre suas cantoras prediletas.

No intuito de deixar as entrevistas mais fluidas, utilizei uma estratégia que consistia em estudar detalhadamente (e previamente) o ro- teiro de perguntas a fim de que essas questóes aparecessem "espontaneamente" na entrevista sem que eu tivesse a necessidade de ler o roteiro na frente do interlocutor. Esta foi uma saída para proporcionar o estabelecimento de um diálogo em que o interlocutor não se sentisse entrevistado (embora soubesse que estava inserido numa entrevista), preso a um sistema de perguntas e respostas e submetido a responder a uma determinada quantidade de questóes que esses tipos de roteiro estabelecem. Tentei proporcionar uma sensação de fluidez em que as perguntas não fossem percebidas - à primeira vista - como uma sequência lógica, mas que fossem sentidas como se tivessem surgido "no calor da hora", originadas somente a partir do que estava sendo dito pelo entrevistado naquele momento. As entrevistas nunca seguiram a mesma ordem de perguntas. As indagaçóes apareciam em uma sequência aleatória, aproveitando as "deixas" dos discursos emitidos, encaixando-se nas frestas situadas entre a carreira da cantora e vida do interlocutor. Essa foi uma tentativa de amenizar a sensação de "ser entrevistado".

Apresentadas todas estas vozes, as condições de trabalho e a forma como a pesquisa foi conduzida, sinto-me à vontade para iniciar a exposição destes diálogos e das reflexôes que fui estimulado a ter a partir deles. Passemos, portanto, à discussão das noçóes de "poder", frequentemente vinculadas a essas cantoras por seus făs, na forma do adjetivo "poderosa”, um qualificador direcionado à classificação, hierarquização, comparação, qualificação e representação dessas artistas.

\section{Poderosa por quê?}

Inicialmente, é importante frisar que esta etnografia tem como principal intuito a com- 
O QUE É QUE UMA DIVA TEM? CANTORAS BRASILEIRAS, VOZES, CORPOS E PODERES VISTOS POR ENTENDIDOS | SI

preensão de três grandes qualificadores frequentemente acionados por fấs homossexuais para designar suas cantoras prediletas, são eles "poderosa", "divina" e "maravilhosa”. Esses adjetivos nem sempre aparecem configurados dessa maneira nas falas dos interlocutores com quem dialoguei, mas surgem em sinônimos equivalentes - muitas vezes em formato de substantivo e não adjetivo - que concedem status de poder, divindade ou glamour a estas artistas. Sendo assim, uma cantora pode ser chamada de "rainha" (numa alusão a uma figura de poder ou ao adjetivo "poderosa"), "deusa" (referindo-se a uma condição de divindade) ou ainda glamourosa (dizendo respeito a um status de refinamento estético da arte e da performance desenvolvida por essas mulheres ou ainda ao modo elegante com o qual esses ídolos se comportam em suas apariçóes públicas). Portanto, de uma forma ou de outra, essas cantoras são constantemente elevadas à condição imaginária de "rainhas", "deusas" e "divas", justamente por serem detentoras de um saber musical e corporal específicos, valorizados por seus fấs homossexuais.

Neste artigo, a discussão estará centralizada na compreensão do significado da noção de poder, utilizada no entendimento de meus interlocutores. Pirata relatou um caso interessante para começarmos esta abordagem:

(PIRATA) - Eu tava conversando com uma amiga e ela me falou que adorou a gravação de "Dê um Rolé" [composição de Moraes Moreira e Galvão feita na época da existência do grupo "Novos Baianos"] que a Roberta Sá5 fez. Eu disse pra ela que a gravação da Roberta Sá pode até ser bonita, mas que, pra mim, essa música marcou com a Gal [Costa]. Essa música é a cara da Gal, né? [perguntando como que para si mesmo] Aí, tá. Fui pro You Tube [referindo- se ao site de compartilhamento de vídeos www. youtube.com] atrás da Gal cantando essa música. Olha... [pausa enfática] eu vi ela cantando "Dê um Rolé" naquele show "O sorriso do gato de Alice". Menino, a mulher tá po-de-ro-sa! Não tá? Gente, o que é aquilo? Essas cantoras de hoje em dia náo tem peito pra cantar que nem a Gal...

Ao escolher a denominação "po-de-ro-sa" para referir-se a Gal Costa, separando as sílabas da palavra para dar destaque a este qualificador, ao mesmo tempo em que afirma que "as cantoras de hoje em dia não têm peito pra cantar que nem a Gal", Pirata define que o poder de Gal Costa está ligado à forma de cantar. Esta "forma de cantar", neste caso, não está circunscrita à emissão da voz, mas percebida no uso do corpo na performance, visto que o vídeo que provocou esta opiniāo de Pirata foi extraído de um dos espetáculos mais teatrais da carreira desta artista. A palavra "peito", usada por Pirata, adquire também um entendimento dúbio, pois era neste show que Gal Costa exibia os próprios seios - como é de conhecimento público devido à repercussão que este espetáculo teve em 1994 - no instante em que cantava a música "Brasil" (de Cazuza, George Israel e Nilo Romero). Assim, ao dizer que "as cantoras de hoje em dia não têm peito pra cantar que nem a Gal", o substantivo "peito" ganha status de sinônimo do adjetivo "coragem". A traduçâo correta do sentido empregado por Pirata em sua construção discursiva diz respeito a um fator de poder atribuído, por ele, à Gal Costa devido a sua maneira de cantar e a sua coragem de performatizar, cenicamente, este canto.

Pretendo, nesta etapa, compreender o significado das palavras e da semântica utilizadas por esses fấs homossexuais para designar os seus ídolos como "poderosas". Em conversa 
com Fatal, pude observar que suas representaçôes de poder estão, de algum modo, relacionadas, mais especificamente, com dois pólos específicos da carreira de Gal Costa: o grito e a delicadeza.

(RAFAEL) - E se tu fosses definir a Gal com alguma palavra, algum adjetivo... Que adjetivo tu usarias para dizer: a Gal é "isso"?

(FATAL) - Uma diva.

(RAFAEL) - Diva... E o que é que uma diva tem? (FATAL) - Poder. Ela [Gal Costa] é a perfeição! Porque a voz dela é algo sublime, é algo invejável. Parece que a Gal não faz força pra cantar...

(RAFAEL) - Mas esse poder está na voz ou em outras características?

(FATAL) - Eu acho que tá na voz e também no que ela representa pra Música Popular Brasileira. Até [pel]a própria situação em que ela virou uma porta-voz do Tropicalismo. Então, através da voz dela, o Caetano [Veloso] falava o que tinha vontade e o [Gilberto] Gil também. Ela levava a coisa de brigar com o Regime Militar, né? Brigar com o governo, alertar as pessoas, gritar com as pessoas: "Acorde, o mundo tá aí! Acho que precisa fazer alguma coisa pra mudar".

O discurso de Fatal confronta duas grandes subdivisóes identificadas na carreira de Gal Costa: a sutileza e a agressividade. Ao mesmo tempo em que Fatal a associa aos vocábulos "perfeição" e "sublime", atribuindo à sua forma de cantar um caráter "invejável”, também a vincula aos verbos "brigar" e "gritar", evocando um caráter "agressivo" para suas interpretaçóes. Suas palavras possibilitam inferir que, tais características, são somente acessíveis às divas, entendendo-se por este qualificador uma artista de grande apuro técnico, segura de seu desempenho musical como cantora, capaz de promover uma sublimação da própria voz. $F a-$ tal ainda sugere que esse poder também pode ser medido pela atuação de Gal Costa no movimento Tropicalista. Para ele, o fato de ter se tornado uma porta-voz da Tropicália durante o exílio de Caetano Veloso e Gilberto Gil, confere à cantora um grau de importância que a coloca num patamar superior, mas também revela uma artista que não apenas canta, mas grita, remetendo-nos ao período em que gravava cançóes vinculadas ao universo do Rock'n Roll.

Em contrapartida, para Atrevido, Fafá de Belém poderia ser classificada como "poderosa” por conta de características que estão além da forma com que canta e mais ligadas ao fator "atitude".

(ATREVIDO) - Eu gosto de ver ela atuando, cantando no palco. Mesmo que o povo diga: "Ah! Ela não consegue alcançar as mesmas notas que antigamente...”. Não consegue mesmo, a gente vê. Mas eu gosto da atitude dela. Eu gosto. Ela tem presença de palco, né? Ela chega descalça, dançando... Isso é forte, tá entendendo? Eu acho legal isso de ver! Ter essa presença, ter essa atitude. Ela é uma mulher de atitude. Isso não tem o que questionar. Ninguém tem tanta atitude. O fato de ela ser daqui também, eu acho, né? Como disse uma vez o Milton Nascimento que lembra dela chegando no cenário [profissional da $\mathrm{MPB}$ ], com as grandes cantoras... Elis vindo do Rio Grande do Sul, né? A Gal e a Bethânia da Bahia, né? Outras de São Paulo e Rio de Janeiro e ela era a única sereia da Amazônia. Eu achei legal isso. Eu acho que pela questão do regionalismo também, por saber que ela é daqui, né?

Ao ser indagado quanto aos "poderes" identificados por ele em Fafá de Belém, Atrevido respondeu que 
O QUE É QUE UMA DIVA TEM? CANTORAS BRASILEIRAS, VOZES, CORPOS E PODERES VISTOS POR ENTENDIDOS 53

(ATREVIDO) - Ela é a única representante de uma regiấo que despontou no cenário nacional. Ela traz o nome dessa regiáo no nome porque Belém é a Amazônia. Então, por isso também... é vinculada com a política... porque move o país. Eu acho que ela tem de tudo um pouco. [risos].

(RAFAEL) - O que seria o poder da Fafá? O "poderosa"?

(ATREVIDO) - Poderosa? Se ela chegar aqui e ter, nos hotéis de Belém, nos dois melhores [hotéis] uma suíte permanente pra ela.

(RAFAEL) - Isso é poder?

(ATREVIDO) - Isso é... uma influência, um poder. Outro poder que ela tem: chegar aqui, fazer um show e ter esse poder de chamar o público, esse apelo. Tem sim. O poder da cantora mesmo, né? A influência. Tem isso.

A fala de Atrevido evidencia a importância concedida ao que ele chama de "atitude". Este substantivo está ligado à expressão "presença de palco", utilizada em sua definição. Para ele, ter presença de palco é ter domínio sobre o corpo, é fazer uso desse corpo para produzir uma representação de força, exteriorizada pelo aspecto gestual, entendendo-se como gestual a própria força da voz, mesmo que esta voz esteja impossibilitada de cantar adequadamente. Entretanto, a voz deve emitir entusiasmo, energia vital e, principalmente, deve sair de uma dimensão etérea - como Fatal reivindicou um caráter de sublimação para a voz de Gal Costa - para conectar-se com fatores mais ligados a uma dimensão terrena, traduzidos pelos pés descalços de Fafá de Belém a reforçarem sua personagem cabocla e amazônica.

Em suas reflexóes acerca dos atributos de poder de seu ídolo, Atrevido deixa transparecer que esse poder se revela em prováveis "homenagens” prestadas a Fafá de Belém como, por exemplo, ter uma suíte exclusiva em cada um dos dois hotéis mais luxuosos de sua cidade natal. Este fã considera como estratégica a associação que a cantora possui com o cenário político local, regional e nacional, o que, certamente, pode abrir-lhe oportunidades profissionais. Finalmente, as palavras de Atrevido deixam escapar que Fafá de Belém possui outra característica que lhe é favorável: o carisma ${ }^{6}$. Esta qualidade se traduz na expressão "esse poder de chamar o público, esse apelo". Pode-se inferir que, no fundo, esse seja um dos "poderes" mais importantes na hierarquia de Atrevido, pois ele o define como "o poder das cantoras mesmo".

Sob lógica semelhante à de Atrevido, Brasileirinho enfatiza a "presença" de Maria Bethânia como um fator diferencial em suas performances e como um atributo de "poder" que o inspira em seu cotidiano.

(BRASILEIRINHO) - Eu acho Bethânia muito guerreira, forte! Uma presença muito forte! [Bethânia é] de chegar [num lugar] e... "Cheguei! Pode vir o resto!”. Por eu ser muito tímido, procuro me espelhar nessa presença dela. Ela me ajuda bastante. Quando eu tenho que chegar num local e tô meio acanhado, eu sempre penso na presença de palco dela.

Há dois outros exemplos pertinentes para chegar a algumas conclusóes acerca dos atributos de poder relativos às cantoras. Durante uma entrevista com o interlocutor Pimentinha e uma conversa informal com Tamba-tajá, dois momentos diferentes da carreira de Gal Costa foram acionados:

(PIMENTINHA) - Rafael, tu já viste o Phono 73, né? A Gal tá liiiinda...!!! Eu adoro a Gal 
cantando com a Bethânia, rodopiando, parecendo uma louca com aquela flor no cabelo, aquela saia... Foi um momento muito poderoso de todas elas... [referindo-se a Gal Costa, Maria Bethânia e Elis Regina - artistas que participaram da série de shows intitulada "Phono 73" e registrada em vídeo pela gravadora Phonomotor]. (RAFAEL) - A Gal estava rouca...

(PIMENTINHA) - Ela não tava cantando nada, mas tava maravilhosa! [risos]

A fala de Tamba-tajá faz referência a outra performance de Gal Costa:

(TAMBA-TAJÁ) - Já assististe o "Mulher 80", né? [programa da TV Globo, gravado em 1979 e lançado em 2008 no formato DVD]. A Gal tá poderosa cantando aquela música... "Eles se amam de qualquer maneira, à vera...” [cantarola]. Gente, eu fico impressionado! Ela corre no palco, pra lá e pra cá, canta, bate no peito. Acho lindo! E ela tá vestindo só um pano que cobre os peitos, bem sensual...

Tais declaraçóes dadas por Pimentinha e Tamba-tajá (fẫs de Elis Regina e Fafá de Belém, respectivamente), incitam à conclusão de que, na percepção deles, o atributo que confere poder a uma cantora, constituindo-a como "ídolo", é o domínio que ela tem sobre o corpo em cena e a capacidade de transfigurar esse domínio num artifício provocador de um magnetismo que prenda a atenção da plateia. Os discursos dos interlocutores são sintomáticos da importância dada ao corpo e de como o valor da corporalidade cênica supera a estima que, geralmente, é dedicada à voz de uma cantora. Principalmente, se essa intérprete é Gal Costa (citada nas duas falas) em que as cobranças recaem, sobretudo, sobre a qualidade da emissão de sua voz e o alcance de sua extensão vocal. Nas performances citadas por esses fấs, Gal Costa não canta da forma que lhe seria desejável como cantora, ou seja, com a "perfeição" técnica que lhe é atribuída pela crítica. Pelo contrário, na primeira performance (1973), sua voz está rouca e a emissão das notas é comprometida pelos rodopios que executa no palco. Na segunda apresentação (1979), sua qualidade vocal é também comprometida pelo seu intenso deslocamento no palco e, talvez, pela falta de preparo físico compatível com a atividade de cantar satisfatoriamente enquanto performatiza. Porém, na percepção destes interlocutores, o corpo, em sua totalidade, fala por si. A sensualidade é também valorizada e a intenção da mensagem é percebida mesmo que o canto esteja prejudicado por algum outro fator.

A partir do contato com esses depoimentos que constroem uma relação entre corpo e noção de poder, sinto-me estimulado a dialogar com os postulados de Mary Douglas (1991) acerca das zonas de poder e de perigo do corpo, pois, de acordo com esta autora, "o corpo humano [...] é matéria de simbolismo; [...] reproduz, a uma pequena escala, os poderes e perigos atribuídos a uma estrutura social." (Ib., p. 138). Ao trabalhar com este universo musical, pretendo mostrar que grande parcela dessas intérpretes está diretamente relacionada a performatividades e partes de seus corpos que, inspirando-me em Douglas (Ib.), seriam avaliadas por mim como zonas de "poder e de perigo", pois apresentam elementos que denotam comportamentos "poluidores" associados à sexualidade não conjugal, homossexualidade, religiosidades não cristãs e vinculação com estilos de vida "alternativos", como veremos a seguir.

Uma observação atenta ao registro, em vídeo, do show "Maria Bethânia Ao Vivo - As Cançóes que você fez pra mim” (dirigido por 
O QUE É QUE UMA DIVA TEM? CANTORAS BRASILEIRAS, VOZES, CORPOS E PODERES VISTOS POR ENTENDIDOS 55

Walter Salles e Andrucha Waddington) possibilita verificar a atenção dispensada a certas partes do corpo como os pés, dedos das mãos, antebraço (fartamente adornado por pulseiras de prata e ouro) e cabelo. Os diretores esforçaram-se em produzir imagens que captassem a expressividade das mãos da cantora a fazer "desenhos" no ar, intensificando suas emoções interpretativas, incitando um gestual de reverência para com seu público e para consigo mesma. O mesmo acontece com a captação de imagens direcionadas aos pés, nas quais $\mathrm{Ma}$ ria Bethânia aparece correndo pelo palco ou, ainda, alongando uma de suas pernas para os lados direito ou esquerdo, tocando o chão apenas com a ponta dos dedos de seu pé enquanto canta notas fortes, impulsivas, aliadas a palavras de impacto coincidentes com mudanças bruscas nos arranjos musicais que revestem as cançóes.

Pirata identifica em Maria Bethânia uma "força" interpretativa que lhe atribuiria o status de "poderosa" a partir da relação corporal construída entre a cantora e a música que interpreta.

(PIRATA) - Se for falar da força dela no palco, eu falaria... eu acho que [Maria Bethânia] é poderosa. Olha, no DVD do [show] "Maricotinha", ela cantando "Fera Ferida" [composição de Roberto e Erasmo Carlos], pra mim aquilo é tão forte. E no final, ela se estapeia mesmo. Ela dá uns tapas no peito que o microfone capta [o som]. [A Bethânia] é uma mulher que canta mesmo, que não tem medo do que ela tem que cantar. Se for uma coisa [música] sofrida, ela vai e enfrenta aquilo.

Fafá de Belém, por sua vez, é sempre associada aos seus próprios seios, lembrada por suas formas corporais "grandes" e pelo exagero de sua gargalhada. Essas referências ao corpo e à gestualidade aparecem nos depoimentos dos interlocutores com quem dialoguei e são, frequentemente, acionadas como atributos de poder ou marcadores que identificam a "atitude" de suas cantoras prediletas. A seguinte fala de Atrevido transparece adjetivaçóes que interseccionam percepçóes corporais, sexualidade e noções de poder.

(ATREVIDO) - Eu acho legal as atitudes dela [Fafá de Belém] como mulher. Ela chegou [começou a carreira] numa época em que o cenário brasileiro, qual era? Muitas cantoras, todas esquálidas, magras... - [como, por exemplo] a Bethânia, a Gal... - e lésbicas! E ela [a Fafá de Belém] chegou gordinha, peituda, dando gargalhada e gostando de homem... [risos] Isso é atitude! Estás me entendendo? E eu gosto disso, dessas coisas dela, eu gosto bastante.

Para Atrevido, os aspectos diferenciais que Fafá de Belém apresentou, quando do seu lançamento no mercado de cantoras nacional, não estiveram estritamente localizados na música ou em suas interpretaçóes vocais, mas, principalmente, nos predicados apresentados pelo seu corpo, no uso do corpo como produtor de imagem e no ato de tornar explícita sua heterossexualidade que, no contexto do mercado musical da época (transição entre os anos 1970 e 1980), contrastava com a homossexualidade predominante atribuída, pelos fã̀s e jornalistas, às "grandes” cantoras da Música Popular Brasileira.

Outro exemplo notório e atual refere-se à percepção consciente que as cantoras constroem de si mesmas. Em 01 de outubro de 2010, ao apresentar o show "Gal Total" em São Paulo, a cantora Gal Costa, no intervalo 
entre duas músicas, falava da roupa escolhida para cantar naquele show e respondia, indiretamente, à cobrança de seus fấs e dos jornalistas para que ela adotasse outro figurino, diferente daquele que já usava em todos os shows daquela longa turnê, que já se prolongava por mais de três anos ${ }^{7}$. Gal Costa disse:

(GAL COSTA) - Eu não preciso de roupa não. O cabelo já tá grande... Vocês [fấs] vão reparar é no cabelo! Porque vocês sabem que o cabelo e a boca são as minhas marcas. Não é a roupa, né? [Faz expressão de desdém] A roupa não é nada. [O que importa] é a voz, cabelo e boca. $\mathrm{E}$ acabou! [aplausos e gritos do público].

A fala da cantora deixa clara a percepção que possui acerca da associação existente entre partes de seu corpo e atributos de poder. É neste aspecto que sugiro um diálogo mais estreito com os trabalhos de Terence Turner (1980) e Mary Douglas (1991), pois a composição visual da obra de Gal Costa evoca, ciclicamente, o uso de sua boca, quase sempre pintada por um batom cuja cor é vermelha, nas capas de seus álbuns.

Apesar de ter pesquisado em contexto indígena (entre os Kayapó), as conclusóes de Terence Turner (1980) auxiliam a pensar nas relaçóes entre cor, corpo e significado. Utilizo a concepção de Turner (Ib.) acerca da roupa e dos acessórios corporais como uma "pele social", acionada pelos indivíduos de um grupo, para compreender que, na performance artística, o figurino é também um demarcador dos diferentes "espaços" ocupados e "papéis" desempenhados pelo artista e pelo público. No entanto, Turner (Ib.) associa cores usadas na pintura corporal dos Kayapó com diferentes partes do corpo e estados de espírito, o que é útil para pensar, de modo análogo, no uso das cores na maquiagem e figurinos das artistas. Para o autor, "a cor vermelha está associada com a noção de vitalidade, energia e intensidade" e geralmente "é aplicada nos pontos periféricos do corpo que estão em contato direto com o mundo exterior", podendo-se exemplificar tais áreas periféricas como sendo "mãos e pés e os órgãos sensoriais da face” (Ib., p. 123, tradução minha).

É interessante observar como essas associações entre cor, roupa, acessórios e partes do corpo representam noçóes de repressão e intensificação que habitam um terreno que está num nível inconsciente, mas que, de alguma forma, surgem explícitas seja na composição visual de um figurino destinado a uma apresentação artística ou na formulação estética da pintura corporal de uma determinada população indígena.

Geertz (1997) apropriou-se dos conceitos psicanalíticos de experiência-próxima e experiência-distante, utilizados por Kohut (apud Geertz, 1997), para afirmar que "as pessoas usam conceitos de experiência-próxima espontaneamente, naturalmente, por assim dizer, coloquialmente; não reconhecem, a não ser de forma passageira e ocasional, que o que disseram envolve 'conceitos"' (Ib.). De acordo com a exposição de Geertz, as noçôes de experiência-próxima e experiência-distante diferem entre si porque a primeira diz respeito às denominaçóes mais usuais, triviais ou comuns utilizadas pelos seres humanos para definir seus sentimentos e vivências; já a segunda refere às designaçôes científicas sobre esses mesmos fenômenos da experiência humana traduzidos racionalmente a partir de uma elaboração à luz de uma linguagem técnica.

Seguindo este raciocínio, é possível sugerir que, muitas vezes, essas noções de repressão e intensificação identificadas por Turner entre os Kayapó são utilizadas e vivenciadas no corpo, 
O QUE É QUE UMA DIVA TEM? CANTORAS BRASILEIRAS, VOZES, CORPOS E PODERES VISTOS POR ENTENDIDOS 57

como uma experiência-próxima, sem que se perceba com total clareza toda a formulação conceitual que se esconde por trás do uso de cores (pintura), roupas e acessórios para adornar certas partes do corpo. Da mesma maneira, um artista pode utilizar determinada composição de cores, roupas e adereços com certo nível de consciência conceitual, mas sendo passível de não conseguir perceber toda a complexidade de significados que sua imagem pode imprimir diante da percepção de seus interlocutores. $\mathrm{O}$ uso da roupa e de todo o seu aparato acessório por parte do performer pode ser realizado de maneira "intuitiva", envolvendo significaçōes sobre as quais não se tem total dimensão de sua representação, caracterizando, dessa forma, a vivência de conceitos no corpo que, na verdade, são resultantes de um saber ligado a uma experiência-próxima, a uma consciência cotidiana.

Assim, interpreto que os lábios de Gal Costa e sua constante associação com o uso de batom vermelho estáo, de certa forma, associados aos conceitos de repressão e intensificação descritos por Turner, na medida em que servem para reforçar a fabricação de sua condição feminina como uma cantora marcada pela intensidade e sensualidade de suas performances dentro de um contexto politicamente repressor e machista: a Ditadura Militar que estava instaurada no Brasil no momento em que o Tropicalismo (movimento musical ao qual a cantora estava vinculada) eclodiu. $\mathrm{O}$ objeto de maquiagem (batom) e a cor vermelha foram, ciclicamente, evocados em sua obra nos álbuns "FA-TAL" (1971); "Gal Tropical" (1979); "Profana" (1984) e "O sorriso do gato de Alice" (1993)

Aproximando-me das contribuiçóes de Mary Douglas (1991), entendo que o conceito de "margens do corpo" não se configura como algo determinado ou fixo. Pelo contrário, as zonas corporais "centrais" e "periféricas" do corpo podem ser percebidas como tal de acordo com o ponto de vista do observador e da cultura na qual está inscrito. A partir dessa concepção instável do conceito de "centro" e "periferia", sugiro que as partes do corpo acionadas por cantoras como Fafá de Belém, Gal Costa e Maria Bethânia (considerando o período histórico em que essas cantoras foram lançadas no mercado fonográfico) foram mobilizadas na condição de "margens" e não de "zonas centrais", pois ostentam elementos "poluidores" (Ib. Idem) que sugerem uma desestabilização da ordem social hegemonicamente aceita ao legitimar "personagens" que, em geral, são estigmatizadas pela sociedade como "sapatáo", "vulgar", "maconheira", "macumbeira", "baiana”, "cabocla", "índia", "safada", "hippie” etc.

Durante a formação de uma imagem pública para Fafá de Belém (seios), Gal Costa (boca e cabelo) e Maria Bethânia (mãos, pés e cabelo), foi notável a articulação realizada entre estas cantoras e determinadas partes de seus corpos. Entretanto, pretendo demonstrar, neste momento, as motivaçóes que me levam a crer que essas partes do corpo foram mobilizadas como "zonas marginais" interessantes para compor a imagem pública dessas artistas.

Começando por Fafá de Belém e considerando que em 1975 (ano de seu lançamento nacional) não havia no Brasil uma cultura maciça de aumento dos seios através de intervenção cirúrgica, é possível sugerir que os seios da cantora foram acionados como "zonas marginais" do corpo, pois além de divergirem dos padróes estéticos hegemônicos e socialmente desejáveis entre mulheres "respeitáveis", os seios de Fafá de Belém eram constantemente evocados em seu material publicitário como deslocados das funções "naturais" de reprodução e amamentação. Assim, a imagem de Fafá de Belém foi construída como uma mulher "farta", "abundante" de desejos e "cheia de amor para dar", 
sendo os seios os principais marcadores desse modelo de mulher sexualmente ávida e, por esse motivo, "poderosa" e "perigosa". Deslocados de suas funçóes maternas e considerando o período historicamente mais conservador em que esse deslocamento foi produzido, os seios foram utilizados para denotar "funçóes marginais" vinculadas ao sexo não reprodutivo e ao prazer desvinculado do casamento. A veiculação da imagem de Fafá de Belém como uma "personagem" pouco ligada às convençóes de conjugalidade exigidas para uma mulher "de respeito", simbolicamente, desestabilizava a inserção desta "personagem" no sistema de "sexo/ gênero” (Rubin, 1975) socialmente aceito em nossa sociedade.

É interessante notar que até mesmo seu repertório foi mobilizado neste sentido. O bolero "Sob medida" - composto por Chico Buarque e gravado por Fafá nos anos 1970 - descreve a realidade de uma mulher "bandida" e "solta na vida" que exerce certo "domínio" sobre o homem amado através de predicados sexuais vinculados à vulgaridade e ao descompromisso conjugal. Isto quer dizer que a personagem "Fafá de Belém" foi construída a partir de pressupostos que negam a condição da mulher "fiel", "passiva" e, principalmente, "discreta". De certa maneira, uma mulher à margem do padrão comportamental legitimado na época.

Com relação à Gal Costa, é necessário também considerar o momento histórico em que sua boca e seus cabelos foram utilizados como representantes de sua identidade performática. O ano de 1970 marcou a primeira vez em que os cabelos da cantora foram evocados como um símbolo de rebeldia na capa do álbum "LeGal".

A utilização do cabelo como um recurso cênico, carregado de significaçôes simbólicas associadas a Gal Costa, foi explorada pelo artista plástico
Hélio Oiticica ao desenvolver a capa e o design gráfico do Long Play (LP) “LEGAL” (1970), no qual havia uma fotografia onde, dentro dos cabelos de Gal, estão contidos vários ícones, da cultura brasileira e mundial, pertencentes ao imaginário dos jovens como, por exemplo, Gilberto Gil, Waly Salomão e James Dean. São, na verdade, fotos de personalidades e eventos sociais que representam as tensōes políticas, sociais e artísticas de uma época e que, neste caso, também estavam representadas implicitamente pela rebeldia dos cabelos da cantora (Noleto, 2011, p. 4-5).

Neste momento histórico, o uso de um cabelo desgrenhado simbolizava rebeldia de comportamento e estabelecia fortes ligaçóes com os movimentos hippie, rock e black power, vigentes na época. A vinculação com estas realidades "sócio-musicais" identificava o sujeito como situado dentro de um contexto "marginal" de sociabilidade, optando por formas alternativas de vida e afetividade. É neste sentido que pretendo alinhavar o uso do cabelo de Gal Costa a uma noção de "periferias do corpo".

O mesmo pode ser percebido quanto ao uso da boca nas capas dos álbuns desta cantora. Num contexto de ditadura militar, a boca de Gal Costa foi utilizada, pela primeira vez na capa do LP "FA-TAL: Gal a todo vapor" (1971) como um elemento que denota uma ampla simbologia. Este álbum

É repleto de simbologias a começar da capa ilustrada com a boca de Gal Costa por trás do microfone que usa para cantar. Além do forte apelo sexual da boca (que se tornaria, a partir de então, emblema representativo da presença física da cantora), a foto dá margem a interpretaçóes de que a boca pode ser usada para cantar, 
O QUE É QUE UMA DIVA TEM? CANTORAS BRASILEIRAS, VOZES, CORPOS E PODERES VISTOS POR ENTENDIDOS 59

calar, denunciar ou até relacionar-se sexualmente (Noleto, 2010, p. 23-24).

Baseado nessa polissemia produzida em torno da boca, principalmente no que diz respeito à sua condição de possível emissora de discursos (cantados ou falados) dentro de um contexto em que o país vivia sob tutela de um regime não democrático, pretendo sugerir que a boca de Gal Costa também pode ser percebida como uma zona periférica do corpo (e, portanto, uma representação de "poder e de perigo”), pois implicitamente incitava discursos e comportamentos discordantes dos padróes hegemônicos da época.

O mesmo raciocínio é utilizado para analisar as mãos e os pés de Maria Bethânia. Fortemente vinculada ao candomblé, Maria Bethânia foi uma cantora pioneira na Música Popular Brasileira no que diz respeito a colocar a sua religiosidade como um fator relevante para a constituição de sua obra. É notável em seu repertório a grande quantidade de gravações de "pontos de santo" que remetem ao culto dos orixás africanos. Apesar de hoje o Brasil ser considerado um Estado laico, a predominância histórica do catolicismo entre as camadas brancas e ricas da população contribuiu para que as religiôes afro-brasileiras fossem estigmatizadas como crenças "inferiores", "primitivas", "marginais" e até "maléficas". Ao mesmo tempo em que foram estigmatizadas, essas religiosidades também tiveram - seguindo o raciocínio de Douglas (1991) - suas capacidades mágicas reconhecidas, visto que "o poder mágico atribuído à macumba e ao candomblé é um corolário da posição socialmente marginal de seus produtores" (Fry, 1982, p. 49). Maria Bethânia, portanto, desde o início de sua carreira em 1965, sempre esteve ligada à imagem de "cantora macumbeira”. A partir desta constatação, analiso que a valorização de suas mãos e pés em todo o seu material discográfico, vídeos e material publicitário, pode também ser interpretada como uma simbologia que ativa "margens" do corpo. $\mathrm{Na}$ interpretação que tento sugerir, as mãos podem ser ressignificadas como partes do corpo, simbolicamente, capazes de lançar feitiços, acionar poderes, apontar caminhos e empunhar "armas de guerra”, a exemplo da orixá guerreira da cantora, Yansã, à qual Maria Bethânia é frequentemente associada (Passos, 2008).

Com relação aos pés descalços, até hoje adotados por Maria Bethânia em seus shows, eles podem ser considerados como fortes símbolos de seu vínculo com a religiosidade e cultura africana, evidenciando conexões com as danças empreendidas nos rituais de candomblé e nos sambas de roda do recôncavo baiano (região onde nasceu), todas elas dançadas com os pés descalços. Além disso, cantar com pés descalços não era, na época em que Maria Bethânia iniciou essa prática, uma atitude esperada dentro da performance musical de qualquer cantora. Vale lembrar que Gal Costa, neste mesmo período, também utilizava os pés descalços como recurso performático, embora essa atitude esteja também relacionada ao universo underground do rock.

O que há em comum entre estes três exemplos de Fafá de Belém, Gal Costa e Maria Bethânia é que essas partes do corpo podem não ser necessariamente percebidas, na atualidade, como zonas periféricas, detentoras de "poderes" e "perigos". A crescente exploração midiática da imagem da mulher exercendo sexualidades não reprodutivas e a maior abertura para a promoção do respeito à diversidade religiosa (sobretudo a partir da Constituição Federal de 1988) faz com que seios, bocas e religiosidades não cristâs deixem de ser percebidos como fatores de marginalidade. Porém, para os fấs dessas cantoras é importante o reconhecimento de 
que essas artistas foram, um dia, consideradas "marginais" e transgressoras. Sugiro que decorre daí o fato de que ainda hoje essas cantoras mantenham ativadas essas simbologias em torno de seus corpos: como uma forma de evocar a constituição de suas trajetórias como figuras públicas aliadas aos parâmetros da transgressão.

A partir da composição de um contraponto entre a presente pesquisa e as conclusóes de Douglas (1991), é possível inferir que a percepção e as conceituaçóes de poder manifestadas pelos meus interlocutores ao longo das entrevistas, são condizentes com a compreensão de que "se é verdade que tudo simboliza o corpo, também é verdade [...] que o corpo simboliza tudo.” (Ib., p. 145). As partes do corpo que são, geralmente, percebidas pelos interlocutores como identificadoras de "poderes" ou que são reforçadas pelas próprias cantoras nas capas de seus álbuns, nos vídeos de seus shows ou mesmo em suas entrevistas, são interpretadas, neste trabalho, como zonas periféricas do corpo porque denotam comportamentos socialmente e historicamente marginalizados.

Assim, ainda na perspectiva de Douglas (Ib. Idem), "seios", "boca”, "cabelo", "dedos", "mãos" e "pés", podem ser interpretados tanto como extensores da expressividade vocal quanto como zonas de "poder e perigo" ativadas na performance dessas artistas. Tais zonas de "poder e perigo" são fragmentos do corpo percebidos, por estes homossexuais com quem mantive contato, como fatores que realçam uma condição de poder. E com esta configuração sugiro que, provavelmente, a própria orientação homossexual de meus interlocutores seja influente nesta percepção dessas zonas do corpo, que considero como "periféricas", como um dos maiores atributos de poder utilizados por essas cantoras. Sugiro que por terem sido historicamente estigmatizados por suas sexualidades, os fấs homossexuais atribuem, com mais frequência, características de "poder e perigo" a essas partes do corpo evocadas no discurso performático dessas mulheres. Isto é, parece haver um encontro de "marginalidades" que permite um reconhecimento e identificação entre o aspecto "marginal" da sexualidade dos fấs e as prováveis "marginalidades" presentes nas trajetórias artísticas dessas intérpretes. $\mathrm{Na}$ realidade, ao identificar esse encontro (ou empatia) entre supostas marginalidades, pretendo situar esse fato como um derivado da própria expressão da lógica queer: apropriar-se daquilo que é considerado, socialmente, como abjeto para, a partir disso, "desenvolver uma analítica da normalização" (Miskolci, 2009, p. 151). A aproximação com o socialmente marginal seria, nestes termos, o caráter queer que dá significado às performances dessas artistas aos olhos de um público homossexual.

Internacionalmente, é possível exemplificar que cantoras como Cher, Madonna e Lady $\mathrm{GaGa}$ - pertencentes a três geraçôes diferentes - assiduamente se utilizam de aspectos "marginais" de seus corpos e suas biografias para produzir performances. Estas cantoras são amplamente reconhecidas pelo público homossexual como mulheres "poderosas" pelo uso que fazem de seus corpos, sexualidades e discursos durante o fenômeno da performance musical. Nestes casos, assim como nos exemplos brasileiros, há uma identificação, entre fã e cantora, pautada na não conformidade aos padrôes hegemônicos de comportamento, simbolizados por figurinos ousados, letras de cançôes homoafetivas e pelo destaque dado ao exercício de uma sexualidade não reprodutiva. Sendo assim, considero que há, para os fấs gays, uma identificação mais imediata com relação aos fatores que podem ser considerados como marginais nessas cantoras.

É nesta perspectiva que trabalho com uma visão homossexual (e masculina) específica 
O QUE É QUE UMA DIVA TEM? CANTORAS BRASILEIRAS, VOZES, CORPOS E PODERES VISTOS POR ENTENDIDOS |6I

sobre certas cantoras da MPB, pois é muito comum ouvir opinióes divergentes destas, sobretudo emitidas por mulheres heterossexuais que não compartilham desses padróes de feminilidade e beleza ostentados por essas artistas. É comum encontrar opinióes em que os cabelos de Gal Costa e Maria Bethânia são considerados como "horríveis e secos", os seios de Fafá de Belém - principalmente antes da popularização dos implantes de silicone para aumento dos seios através de intervenção cirúrgica - vistos como "exagerados" e, ainda, as cores dos batons escolhidos por Gal Costa como "muito chamativas”. Se submetidas à apreciação de seus fấs homens heterossexuais, mulheres homossexuais e mulheres heterossexuais, provavelmente, essas cantoras teriam essas partes de seus corpos reconhecidas e valorizadas (ou desvalorizadas) a partir de diferentes sistemas de valoração. São sistemas complexos que coincidem e divergem entre si, entrecruzando valores morais, sexualidades e subjetividades diversas para produzir uma avaliação acerca de "pés descalços", "seios avantajados", "cabelos alvoroçados", "bocas avermelhadas", dentre outras configuraçốes corporais apresentadas por essas intérpretes.

Em depoimento concedido por um de meus entrevistados, Pimentinha, fica clara a valorização dos aspectos corporais de Elis Regina quando este evidenciou grande satisfação ao discorrer sobre o show "Essa Mulher" (1979) no qual, em suas palavras,

(PIMENTINHA) - Elis deixou o cabelo crescer, ficou mais feminina, botou flor no cabelo, investiu num lado 'mais mulher' pra fazer esse show. Ela topava essas coisas. Ela era esperta! Se tinha que mudar pra vender mais, mudava mesmo. E eu acho ela liiinda e poderosa nesse momento...!
Nestes termos, o poder das cantoras está situado no corpo, um corpo que também é voz, mas que náo se resume a ela. Ao longo do trabalho de campo, era para o corpo que os discursos apontavam. Foram recorrentes depoimentos que indicavam sinais de "poder" percebidos nos corpos e nos comportamentos dessas artistas. Exemplos disso são as referências que meus interlocutores faziam a gestos, olhares, poses, roupas, modos de falar, formas de rir e, sobretudo, à imagem estética dos corpos ostentada por essas intérpretes em seus shows, aparições públicas em eventos, ensaios fotográficos e apresentações em programas de televisão. Os discursos revelavam uma valorização das "técnicas corporais" (Mauss, 1974) como atributos de poder tanto "dentro" quanto "fora" da performance musical. Isso implica dizer que tal entendimento demonstra a existência de uma imbricação entre técnicas cotidianas de um fazer corporal (Ib. Idem) e técnicas extra-cotidianas de um fazer performático voltado para a música (Laboissière, 2007), possibilitando articular a noção de que a performance não começa nem se encerra no show, mas se expande para outras realidades em que a cantora atua.

\section{What have a diva got? Brazilian female singers, voices, bodies and powers viewed by experts}

abstract Within certain homosexual social networks, the adjective "powerful" is often operated as a marker for the classification, comparison, qualification and representation of female idols admired by gay men. Based on ethnography conducted in Belém (Pará), this paper aims to understand what are the notions of power articulated by gay men - with identity and gender performance recognized, by them, 
as masculine - to describe their favorite female singers. Showing that, in most speeches, this "power" of female singers transcends strictly musical predicates and it is revealed rooted in all performance of their bodies, this paper discusses about the "powers", "dangers", "centralities" and "peripheries" of the body.

keywords Homosexuality. Performance. Female Brazilian Singers. MPB. Body.

\section{Notas}

1. Esta classificação não diz respeito à orientação sexual das cantoras, mas à orientaçáo sexual da maioria de seus fấs, de acordo com os depoimentos fornecidos por meus interlocutores.

2. Utilizo esse termo para designar um conhecimento referente ao mundo da moda (ou, em inglês, ao universo "fashion") através do qual se pode reconhecer as tendências futuras, o passado e o presente da moda.

3. O termo é usado no mesmo sentido em que Carmen Dora Guimarães (2004) o emprega em "O homossexual visto por entendidos". Relações homossociais consistem em vínculos não necessariamente sexuais entre sujeitos que integram uma rede de sociabilidade homossexual.

4. O Parque da Residência é o antigo local onde todos os políticos eleitos como governadores do Estado do Pará eram conduzidos a fixar residência durante seus mandatos. Localizado no bairro de São Braz, em Belém, atualmente, este local foi transformado em ponto turístico da cidade, abrigando um teatro, um restaurante, uma sorveteria e um parque com algumas espécies de plantas e orquídeas expostas ao público. $\mathrm{O}$ palacete onde antigamente moravam os governadores é utilizado como sede da Secretaria de Estado de Cultura do Governo do Estado do Pará.

5. Cantora lançada, nacionalmente, nos anos 2000 e considerada como pertencente à chamada "nova geração" de cantoras de MPB.

6. Geertz (1997) aprofunda a discussão sobre os atributos simbólicos do carisma ao defini-lo como "um sinal de envolvimento com os centros que dão vida à sociedade" (p. 186), mesmo que o indivíduo "ca- rismático" - em seu envolvimento - represente uma oposição aos valores cultivados nesses centros da vida social. No caso das cantoras abordadas neste artigo, acredito que elas desempenharam funções, de certa forma, opositoras a ideias hegemônicas de feminilidade, sexualidade e religiosidade no período histórico em que foram lançadas no mercado fonográfico brasileiro. Daí, talvez, a proximidade com a ideia de carisma e a possibilidade de enxergá-las como cantoras "marginais" não porque estejam à margem, mas porque se opóem aos "centros".

7. O video que contém esta fala foi por mim registrado e disponibilizado no link: http://www.youtube.com/ watch? $v=B C r Q 3 e o q I 5 g$

8. Ver artigo "Gal Costa e o tropicalismo no feminino: corpo, subjetividade e sexualidade no discurso performático" no qual analiso possíveis intersecções entre performance musical, erotismo e sexualidade. Disponível em: http://www.xcaas.org.ar/grupostrabajosesiones.php? eventoGrupoTrabajoCodigoSelecci onado=GT49

\section{Referências bibliográficas}

BOURDIEU, Pierre. A distinção: crítica social do julgamento. São Paulo: EDUSP; Porto Alegre: Zouk, 2007.

BUTLER, Judith. Problemas de gênero: feminismo e subversão da identidade. Rio de Janeiro: Civilização Brasileira, 2010.

CARRARA, Sérgio; SIMÓES, Júlio. Sexualidade, cultura e política: a trajetória da identidade homossexual masculina na antropologia brasileira. Cadernos Pagu, n. 28, jan/jun, 2007.

DOUGLAS, Mary. Pureza e Perigo: ensaio sobre as noçôes de poluição e tabu. Tradução de Sónia Pereira da Silva. Lisboa: Ediçôes 70, 1991.

FRY, Peter. Para inglês ver. Rio de Janeiro: Zahar Editores, 1982.

FRY, Peter; MACRAE, Edward. O que é homossexualidade? (Coleção Primeiros Passos, n. 26). São Paulo: Abril Cultural e Editora Brasiliense, 1985.

GEERTZ, Clifford. A interpretação das culturas. Rio de Janeiro: LTC, 1989. - O saber local: novos ensaios em antropologia interpretativa. Petrópolis: Vozes, 1997.

Obras e vidas: o antropólogo como autor. Tradução 
O QUE É QUE UMA DIVA TEM? CANTORAS BRASILEIRAS, VOZES, CORPOS E PODERES VISTOS POR ENTENDIDOS $\mid 63$

de Vera Ribeiro. Rio de Janeiro: Editora UFRJ, 2009. GUIMARĀES, Carmen Dora. O homossexual visto por entendidos. Rio de Janeiro: Garamond, 2004.

LABOISSIÈRE, Marília. Interpretação Musical. São Paulo: Annablume, 2007.

LOURO, Guacira Lopes. Gênero, sexualidade e educaşão: uma perspectiva pós-estruturalista. Petrópolis: Vozes, 1997.

MALINOWSKI, Bronislaw. Argonautas do Pacifico Ocidental. São Paulo: Abril Cultural, [1922] 1976.

MARTIN, Emily. A mulher no corpo: uma análise cultural da reprodução. Tradução de Júlio Bandeira. Rio de Janeiro: Garamond, 2006.

MAUSS, Marcel. Sociologia e Antropologia. Vol. II, Sáo Paulo: EPU/EdUSP, 1974.

MAYBURY-LEWIS, David. O selvagem e o inocente. Campinas: Editora Unicamp, 1990.

MISKOLCI, Richard. Teoria queer e a sociologia: o desafio de uma analítica da normalização. Sociologias. Porto Alegre, ano 11, n. 21, jan/jun: 150-182, 2009.

NOLETO, Rafael da Silva. Meu nome é Gal: um grito feminino no Tropicalismo. Trabalho de Conclusão de Curso (Licenciatura em Música) - Centro de Ciências Sociais e Educação, Universidade do Estado do

\section{autor \\ Rafael da Silva Noleto \\ Mestrando / PPGA-UFPA}

Recebido em 26/03/2012

Aceito para publicação em 01/10/2012
Pará, Belém, 2010.

. Gal Costa e o tropicalismo no feminino: corpo, subjetividade e sexualidade no discurso performático. In: CONGRESO ARGENTINO DE ANTROPOLOGÍA SOCIAL, X, 2011, Buenos Aires. Anais... Buenos Aires: Universidad de Buenos Aires, 2011. Disponível em: http://www.xcaas.org.ar/grupostrabajosesiones.php?eventoGrupoTrabajoCodigoSelecci onado=GT49. Acesso em: 15 fev. 2012.

PASSOS, Marlon Marcos Vieira. Oyá-Bethânia: os mitos de um orixá nos ritos de uma estrela. Dissertação (Mestrado) - Programa de Pós-Graduação em Estudos Étnicos e Africanos, Universidade Federal da Bahia, Salvador, 2008.

PEIRANO, Mariza. A favor da etnografia. Série Antropologia, UnB, no 102, 1990.

RUBIN, Gayle. The Traffic in Women. Notes on the "Political Economy" of Sex. Toward an Anthropology of Women. REITER, Rayna (ed.). New York: Monthly Review Press, 1975.

SILVA, Vagner Gonçalves da. O antropólogo e sua magia: trabalho de campo e textos etnográficos nas pesquisas antropológicas sobre religiōes afro-brasileiras. São Paulo: EDUSP, 2006.

TURNER, Terence $S$. The social skin. In: CHERFAS, J. Not Work Alone. (ed.). London: Temple Smith, 1980. 